\title{
The Role of Audit Committees in the Libyan Banking Sector as it Transforms into an Islamic System
}

\author{
Abdulhakim M Masli* Musa Mangenac ${ }^{* *}$ Donald Harradined ${ }^{* * *}$
}

Received: 20.11 .2018

Accepted: 08.07.2019

DOI: $10.25272 /$ ijisef.485437

Type: Research Article

\begin{abstract}
This paper aims to explore the role of audit committees (ACs) in the Libyan banking sector (LBS) and to investigate the impact on AC practice of the sector's recent shift to an Islamic banking system. Little is known about the role of these committees, which were only made compulsory in Libya in 2010. The findings support agency theory in that they perceived these committees as being responsible for reviewing financial statements, the internal auditing function and the external audit process. However, the perception was that ACs are not currently carrying out these responsibilities effectively; participants perceived ACs as spending too little time reviewing financial statements, rarely challenging weaknesses in the work of internal auditors and seldom following up or supervising the work of external auditors. One explanation for this state of affairs is that ACs in the LBS are primarily designed to create legitimacy outside the organisation rather than to effect radical change within it. The study also found that it is not the application of Islamic law per se that is perceived as having an adverse impact on AC practice in the LBS, but the speed at which this transition is taking place in an already weak banking environment. This research helps expand our knowledge of current AC practice as a key mechanism of corporate governance (CG) by being the first to investigate how this role is performed in Libyan banks, which are in the early stages of implementing Islamic law. The research is also important because it addresses an information gap in the accounting literature by investigating AC effectiveness in a developing country, a context which is still poorly understood.
\end{abstract}

Keywords: Audit committees, Corporate governance, Libyan banking sector, Islamic law, Libyan corporate governance code.

Jel Codes: M4, M410, M420

\footnotetext{
* Nottingham Trent University, 50 Shakespeare St, Nottingham, United Kingdom, Faculty of Economics, Misurata University, Misurata City, Libya, a.masli@eps.misuratau.edu.ly__ORCID: https://orcid.org/0000-0002-2096-9201

** University of Essex, Wivenhoe Park, Colchester CO4 3SQ, United Kingdom, mm17456@essex.ac.uk. ORCID: https://orcid.org/0000-0002-3005-8110

${ }^{* * *}$ Nottingham Trent University, 50 Shakespeare St, Nottingham, United Kingdom, d.harradine@sky.com, ORCID: https://orcid.org/0000-0002-8329-5948
} 


\section{Introduction}

Audit committees (ACs) are central to good corporate governance (CG). According to the Blue Ribbon Committee (1999) and the Smith Report (2003), the role of the AC is to oversee not only the financial report process but also internal control and risk management systems. It is therefore, as Mangena and Pike (2005) suggest, an important element in the CG process. Turley and Zaman (2014) note that recent years have seen a much greater emphasis being placed on AC effectiveness; Fichtner (2010) argues that the Enron collapse in particular led regulators and governments throughout the developed world to pay renewed attention to the AC as one of the key governance mechanisms. Similarly, Rustam et al. (2013) observe that recent corporate scandals in developed countries have resulted in the creation of CG guidelines which give a prominent role to ACs. Rezaee (2009) and Liao and Hsu (2013) identify the roles of the $\mathrm{AC}$ as being to ensure responsible CG, review the firm's financial reporting and provide a channel of communication between the board, external auditors and internal auditors in order to protect the interests of shareholders and other stakeholders.

However, while these are the expectations that surround ACs in developed countries, the lack of an institutional framework for CG in developing countries (Boubakri et al., 2005) means that ACs in these countries are operating in a very different environment. This is likely to have an impact both on practice in these committees and on their effectiveness as mechanisms of CG. The vast majority of studies have focused on developed countries (e.g. Mangena and Pike, 2005; Beasley et al., 2009: Turley and Zaman, 2014), but it is possible that the research findings from these countries may not be applicable to developing countries, where environmental factors (e.g. management quality) may be very different (Barghathi et al., 2016). Among the few studies so far conducted in developing countries (e.g. Al-Moataz, E., 2010; Khlif and Samaha, 2016), those focusing on AC effectiveness have found these committees to be largely ineffective.

The current study aims to explore the role and effectiveness of ACs in the Libyan banking sector (LBS), one of the most important sectors in the Libyan economy (Alrshah, 2015). The sector faces numerous obstacles, including a lack of support from the Central Bank of Libya (CBL) and a lack of trained staff (Zaed et al., 2016), but one of its greatest challenges is its rapid (some would say too rapid) shift to Islamic banking (Stela and Abdulsalam, 2016). The rapid enforcement of Islamic law in an already weak banking environment is likely to adversely affect practice in banks, including CG practice, if it pushes them into changing their systems without proper preparation. For example, Libya does not currently have the qualified staff or Islamic capital market it needs to transition successfully to Islamic banking (Abdalla et al., 2015). It is vital that banks overcome these problems as without efficient systems, including strong CG, they will remain weak and attract few investors (Eldlimi et al., 2013). Supporters of Islamic banking argue that an effective Islamic banking system will attract both the domestic and foreign investment that is crucial to Libya's economy (Eldlimi et al., 2013). 
This paper makes a contribution to the ongoing discussion about AC's role in CG. First, by investigating AC effectiveness in Libya as a developing country, it addresses an information gap - this context is still poorly understood practice in developing countries (Al-Moataz, 2010). By providing new evidence (and a different perspective) from a context that is culturally, socially, legally and politically different from others in the world. Second, the research adds to our understanding of how CG mechanisms operate in Libyan firms by being the first to cover the role of ACs in Libyan banks. Moreover, it is unique in covering the role of ACs in banks that are in the early stages of implementing Islamic law, and in investigating the impact of this transition on AC effectiveness. Given the speed at which this transition is taking place in Libya, and the current weakness of the country's banking environment (Abdalla et al., 2015; Zaed et al., 2016), this exploration is urgently needed. The move towards privatisation and the broadening of ownership, and the need to attract foreign investment (Masoud, 2014a), are further reasons why it is necessary to review and improve the ways in which CG mechanisms operate in the LBS (Larbsh, 2010). This exploration of the role of ACs in the LBS is a useful first step; its findings may help board members, AC members, regulators and shareholders in their decision-making and encourage them to pay greater attention not just to ACs but also to other CG mechanisms. The study, therefore, attempts to enhance our understanding of the concept of CG and the role of ACs, where little is known about how these committees operate in developing countries, such as Libya, which has begun to apply Islamic services in its banks.

\section{Literature Review}

The LBS is one of the most important sectors of the Libyan economy (Alrshah, 2015) and one of the major financiers of national development projects and institutions. Realising its central importance to national economic growth (CBL, 2010), the CBL implemented a series of measures between 2002 and 2010 that were aimed at bringing the sector into line with the international banking system and fostering its development. These included the issuance of a (voluntary) CG code in 2005, the restructuring of commercial banks and the transfer of ownership of some public sector banks to the private sector. New private banks were established and foreign investors and foreign banks were allowed to participate in the sector (CBL, 2010).

In 2010, the Libyan CG Code (LCGC) was finally made mandatory. This code is made up of six sections. The first discusses the central principle of corporate governance and its importance in ensuring that banking operations are conducted safely and protect the interests of shareholders, as well as an explanation of many of the terms used in this code. The second section identifies out the Shareholders' equity including how to make decisions at the General Assembly of Shareholders. The third section sets out the criteria for appointing board members and senior management and explains what they should do in order to perform their duties towards shareholders, depositors and other debtholders efficiently and effectively. This section addresses the board's role in choosing and supervising management, and the relationship between the board of directors and the executive management. Section four sets out the sub-committees of the board of directors for helping the board of directors to perform 
its duties and responsibilities. These sub-committees include AC, corporate governance committee, risk management committee and appointment and remuneration committee, while sections five and six addresses the disclosure of corporate governance practices implemented by banks and some other requirements, such as a number of obligations of public sector shareholders (CBL, 2010a). However, although the LCGC is now mandatory, most Libyan businesses are still in the early stages of implementing CG (Iswaissi and Falahati 2017) and there remain widespread deficiencies. Regulation is still inadequate, there is little training for directors on governance systems, weakness of the legal system that governs the activities (Larbsh, 2010; Magrus, 2012; Zagoub, 2016).

In 2013, Libya's parliament, the General National Congress (GNC), issued a new law authorising the application of Islamic law across the LBS (Stela and Abdulsalam, 2016) through the transformation of all banks from conventional into Islamic institutions. With the strong support of most segments of society (Abdulsaleh, 2017), the CBL began the process of transforming the conventional banking system into an Islamic banking system. However, at the time of writing, the move to an entirely Islamic banking system has not yet been accomplished, and many banks remain in the early stages of transition (Abdulsaleh, 2017; Elkrghli and Yahya, 2018). There are several reasons for this, including a lack of relevant experience and inadequate staff training, changing systems, and Libya's lack of an Islamic financial market (Abdalla et al., 2015; Zaed et al., 2016; Abdulsaleh, 2017; Elkrghli and Yahya, 2018), all of which may affect a bank's governance, including its AC.

The review of literature indicates that the role of the AC is to ensure responsible CG in order to protect the interests of shareholders and other stakeholders (e.g. Rezaee, 2009; Campbell et al., 2013). This includes reviewing and monitoring the internal and external audit functions and the firm's financial reporting (Beasely et al., 2009; Abernathy et al., 2013; Bédard and Compernolle, 2014). In this regard, A number of regulators, such as the Combined Code (UK), suggest that the AC should play a central role in the financial reporting process, actively supervising and monitoring it (Campbell et al., 2013). Abernathy et al. (2013) point out that an effective $\mathrm{AC}$ enhances the reliability and credibility of financial statements for users. In addition, the AC should play a primary role in the internal audit function. Cohen et al. (2004) assert that close interaction between the $\mathrm{AC}$ and the internal audit function improves the governance capabilities of both parties. Governance improves when the internal audit sees the $\mathrm{AC}$ as giving greater weight to their activities within the organisation (Turley and Zaman, 2007) and enhancing their effectiveness and promoting their independence (Ahmad et al., 2009). Furthermore, a significant number of researchers and some regulatory bodies have stressed that the AC should monitor the independence, effectiveness and objectivity of external auditors, make recommendations to the board regarding their appointment and removal and review the results of the audit (e.g. Smith, 2003; Beasley et al., 2009; Rezaee, 2009). The Smith Report (2003), for example, advises that AC should be responsible for reviewing the letter appointing the external auditor, the scope of the audit and the adequacy of the planning process. Bédard and Compernolle (2014) argue that such measures will help ensure the quality 
of the external audit, but no one has yet attempted to explore the role of the AC in Libya. Our study, therefore, addresses an information gap by investigating AC effectiveness in a developing country. This context is still poorly understood in developing countries (AlMoataz, 2010), and there are few studies addressing either CG or ACs in these countries (Okeahalam, 2004). By providing a different perspective from a context that is culturally, socially, legally and politically different from that of the west, it may enhance our understanding of the concept of CG and ACs.

As the main concerns of the study are to identify whether Libyan ACs play a vital role in monitoring financial statements and enhancing the internal audit function and external audit process in the banking sector and to investigate the impact of the shift to Islamic banking on their role where both CG and Islamic law are in the early stages of implementation. The study employed a combination of elements of agency theory and institutional theory to gain the richest understanding of this role in Libya's banking sector. Accordingly, two research questions were framed:

Q1. What is the present role of ACs in Libya's banking sector?

Q2. To what extent is Islamic law perceived as influencing ACs in this sector?

\section{Theoretical Background}

Kalbers and Fogarty, (1998) and Beasley et al. (2009) argue that institutional theory and agency theory offer complementary perspectives for investigating the role and activities of ACs by combining elements of both.

\subsection{Agency Theory}

In the accounting literature, agency theory has been used extensively to explain and interpret accounting practices as a whole (Aldredge et al., 2017). Agency theory posits that there is a fundamental conflict of interest between owners and managers (Gitundu et al., 2016); it assumes that the latter are usually more interested in exploiting the company for their own benefit than in serving the owners' interests (Schroeder et al., 2014). Hussainey and Hassanein (2017) argue that agency problems are most likely to arise where information is asymmetrically shared between principals and agents. It is therefore crucial that the board and AC monitor managers to prevent opportunistic behaviour (Beasley et al., 2009). However, a lack of relevant research means that there is some uncertainty over whether agency problems in Libya are the result of conflicts in the owner-manager relationship (Alrshah and Fadzil, 2013) or in the relationship between majority and minority shareholders (Abdou, 2015). In either case, the implementation of CG mechanisms such as ACs may help minimise these conflicts and mitigate their impact (Alrshah and Fadzil, 2013; Elgharbawy et al., 2016).

\subsection{Institutional Theory}

Usually referred to as "new" institutionalism (Greenwood et al., 2008), institutional theory has been widely utilised to assess the practical influence of CG codes (Solomon, 2013). Beasley et 
al. (2009) illustrate the truth of Fiss's (2007) claim that institutional theory is uniquely positioned to contribute to researchers' knowledge of CG by showing that some governance activities and structures are merely symbolic and are primarily intended to create legitimacy outside the organisation. This is the case in Libya, where the formation of an AC is public evidence of the bank's compliance with the LCGC. While agency theory sees the AC as playing a practical monitoring role, institutional theory sees the $\mathrm{AC}^{\prime}$ 's role as largely symbolic (Kalbers and Fogarty, 1998; Beasley et al., 2009). Accordingly, this is the approach adopted in this research.

\section{Research Methodology}

The study used a combination of questionnaire survey and semi-structured interviews. This is to boost data quality and minimise the risk of bias (Hussey and Hussey, 1997). Data was first gathered from the questionnaire responses. This was supported by the data gathered from the semi-structured interviews, which were used to gain a better understanding of the research questions, and to confirm and further explore the questionnaire survey findings.

\subsection{Questionnaire Survey}

Following Saunders et al., (2009), the questionnaire began with a brief summary outlining the project and the purpose of the questionnaire. It was divided into two sections, the first of which gathered respondents' demographic information (role, educational level, degree subject and work experience). The second section aimed to elicit respondents' perceptions regarding the role of the AC. Participants were asked to indicate whether their AC plays a role in monitoring financial statements and in internal and external auditing, and how it performs this role. Little is known about the status of ACs in Libya, so it was important to gain greater insight into their systems and structure and any perceived deficiencies in performance. The survey questions were developed following the literature review in this area (e.g. Turley and Zaman, 2007; Beasley et al., 2009; Braswell et al., 2012). All of the questions in the second section employed five-point Likert scales.

Since the target population for this study is relatively small, the survey was distributed to all members of the five target groups, rather than to a selected sample. A list of 400 potential respondents was prepared following a search of the banks' websites and telephone conversations with CBL officials. These groups comprised board members, AC members, executive managers, internal auditors and external auditors. These five groups are the most familiar with AC practice, have the means and right to monitor firms, and are widely regarded as the foundation stones upon which a bank's monitoring mechanisms are built (see Rezaee, 2009; Ittonen et al., 2010; Waweru et al., 2011). 246 of the 400 distributed questionnaires were returned, 28 of which were rejected because they were incomplete. This left 218 for analysis, representing a response rate of $54.5 \%$. 


\subsection{The Interview Method}

Interviews can be especially useful in assisting the researcher to access results that cannot be reached through statistical or other quantitative approaches (Corbin and Strauss, 2008), particularly semi-structured interviews (Ritchie et al., 2013). They give the researcher the space and flexibility to pursue new issues as they emerge (Pietkiewicz and Smith, 2014), and the questions and themes explored may differ from one interview to another (Ramlan et al., 2015). They are often used in accounting research, including for the investigation of ACs, because they allow the gathering of more detailed information than is typically collected in quantitative research (Turley and Zaman, 2007; Beasley et al., 2009).

Twenty interviews were conducted with the five groups (four per group) listed above. These groups have the most experience of working with ACs. The interviewees, who were all senior employees, were selected using the snowball method, with interviewees being asked to propose the names of other suitable candidates. Care was taken to choose individuals from a range of banks in order to enhance the credibility of the findings. The interviews, which were conducted face-to-face, allowed the collection of more in-depth opinions. Interviewees were assured that the interview transcripts would remain anonymous and that their identity would be disguised by means of code names (e.g. A0001). They were also assured that data would be stored safely and would remain confidential.

\section{Results And Discussion}

This section discusses the perception of the interviewees and questionnaire respondents about the role of ACs in the LBS. This role includes monitoring the organisation's financial reporting and internal audit function and the external audit process. These are therefore the focus of the following sections.

\subsection{The Ac's Role In Monitoring Financial Statements}

The questionnaire respondents were given a list of statements and asked to indicate the extent to which they agreed that the statements described tasks undertaken by the AC as part of its role as the monitor of financial reporting. Table 1 presents the mean scores for the participants' responses to this question. Statement 4 ("The AC reviews corrections made by management to financial statements") generated the highest aggregated mean score, followed in descending order by statement 3 ("The AC reviews and monitors EA reports concerning financial statements"), statement 2 ("The AC monitors the compliance of the financial statement process with accounting standards") and finally statement 1 ("The AC reviews significant accounting policies").

The highest of these overall group means (3.85) came from the board members (BD) group, indicating that it agreed most strongly that ACs play an active role in monitoring financial statements. The second strongest agreement came from the external auditors (EA) group (3.75), followed by the internal auditors (IA) group (3.70) and finally both the audit committee members (AC) group and the executive managers (EM) group (3.60). The lower mean scores 
from the AC and EM groups suggest that many of the AC members and executive managers in the sample might not have been completely satisfied with how their AC performs this aspect of its role. The Cronbach's Alpha ${ }^{1}$ test generated a value of 0.78 for this question, which is higher than 0.70 , indicating that all the data is reliable.

Table 1: Descriptive Statistics on the Role of the AC in Monitoring Financial Statements

\begin{tabular}{|c|c|c|c|c|c|c|c|c|c|c|c|}
\hline \multirow{2}{*}{ No } & \multirow{2}{*}{ Statements } & \multicolumn{5}{|c|}{ Group Means } & \multirow{2}{*}{$\begin{array}{l}\text { Total } \\
\text { Mean } \\
\text { Score }\end{array}$} & \multirow{2}{*}{ Median } & \multirow{2}{*}{$\begin{array}{l}\text { Standard } \\
\text { Deviation }\end{array}$} & \multirow{2}{*}{ Rank } & \multirow{2}{*}{$\begin{array}{l}\text { Cronbach's } \\
\text { Alpha }\end{array}$} \\
\hline & & $\mathrm{BD}$ & $\mathrm{AC}$ & EM & IA & EA & & & & & \\
\hline 1. & $\begin{array}{l}\text { The AC reviews significant } \\
\text { accounting policies. }\end{array}$ & 3.71 & 3.35 & 3.35 & 3.49 & 3.74 & 3.50 & 4.00 & 1.08 & 4 & \\
\hline 2. & $\begin{array}{l}\text { The AC monitors the compliance of } \\
\text { the financial statement process with } \\
\text { accounting standards. }\end{array}$ & 3.76 & 3.65 & 3.64 & 3.85 & 3.74 & 3.73 & 4.00 & 1.01 & 3 & \\
\hline 3. & $\begin{array}{l}\text { The AC reviews and monitors EA } \\
\text { reports concerning financial } \\
\text { statements. }\end{array}$ & 3.86 & 3.82 & 3.80 & 3.69 & 3.63 & 3.74 & 4.00 & 1.14 & 2 & 0.78 \\
\hline 4. & $\begin{array}{l}\text { The AC reviews corrections made } \\
\text { by management to financial } \\
\text { statements }\end{array}$ & 4.05 & 3.59 & 3.61 & 3.79 & 3.89 & 3.75 & 4.00 & 1.00 & 1 & \\
\hline \multicolumn{2}{|c|}{ Overall Group Means } & 3.85 & 3.60 & 3.60 & 3.70 & 3.75 & 3.68 & - & - & - & \\
\hline
\end{tabular}

Figure 1 shows how the responses to this question were distributed across the sample as a whole. In order to facilitate the process of analysis, the strongly disagree and disagree responses were combined, as were the strongly agree and agree responses. The answers from the midpoint of the Likert scale were placed in the uncertain category. Across the sample as a whole, there was thus a high level of agreement with all four statements. While statement 4 elicited the highest percentage of agree answers (71.6\%), statement 1 generated the lowest $(61.9 \%)$. It should be noted, however, that between $15.6 \%$ and $20.6 \%$ of the sample as a whole were uncertain whether these tasks are undertaken by ACs (or were reluctant to give an opinion). The results in Table 1 and Figure 1 are consistent with those identified in a number of other studies (e.g. Beasley et al., 2009; Campbell et al., 2013).

Figure 1: Overall Results for Respondents' Perceptions of the Role of the AC in Monitoring Financial Statements

\footnotetext{
${ }^{1}$ Cronbach's alpha is the most popular way to measure the reliability of quantitative survey data. The internal consistency of survey items is checked by measuring the extent to which participants' responses correlate with each other.
} 


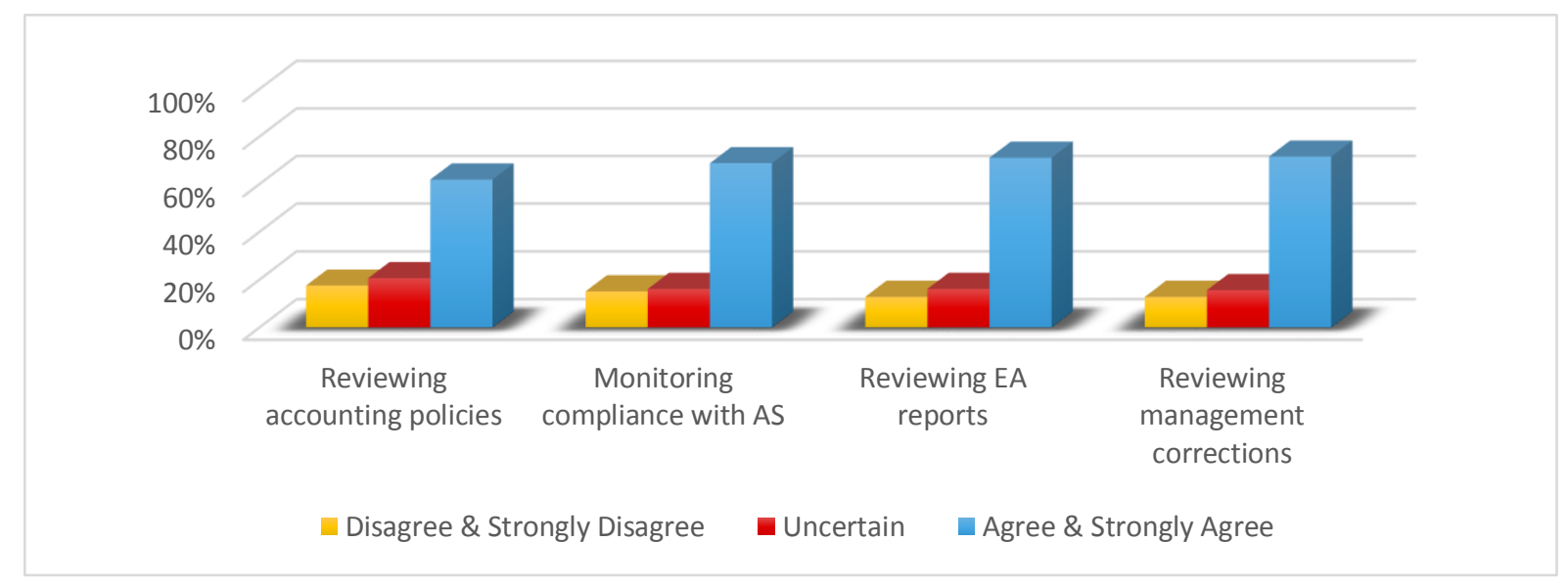

Table 2 shows that the Kruskal-Wallis² test found no significant differences between the groups for any of the four statements, producing values of $0.21,0.94,0.81$ and 0.40 respectively. The Mann-Whitney ${ }^{3}$ test confirmed that there were no statistically significant differences between pairs of groups on this question apart from between the BD group and the EM group on statement 4 . The result here (0.04) may be another indicator that the EM group might not have been totally satisfied with how their AC performs this aspect of its role, as executive managers may be more aware of this issue as a result of their work.

Table 2: Results of Between-Group Comparisons on the AC's Role in Monitoring Financial Statements

\begin{tabular}{|c|c|c|c|c|c|c|c|c|c|c|c|c|}
\hline \multirow{2}{*}{$\mathrm{NO}$} & \multirow{2}{*}{ Statements } & \multirow{2}{*}{$\begin{array}{l}\text { Kruskal } \\
\text {-Wallis }\end{array}$} & \multicolumn{10}{|c|}{ Mann-Whitney Test - P-values } \\
\hline & & & BD-AC & BD-EM & BD-IA & BD-EA & AC-EM & AC-IA & AC-EA & EM-IA & EM-EA & IA-EA \\
\hline 1. & $\begin{array}{l}\text { The AC reviews significant } \\
\text { accounting policies. }\end{array}$ & 0.40 & 0.19 & 0.21 & 0.32 & 0.99 & 0.74 & 0.56 & 0.14 & 0.73 & 0.13 & 0.22 \\
\hline 2. & $\begin{array}{l}\text { The AC monitors the } \\
\text { compliance of the financial } \\
\text { statement process with } \\
\text { accounting standards. }\end{array}$ & 0.81 & 0.80 & 0.90 & 0.50 & 0.86 & 0.89 & 0.46 & 0.74 & 0.24 & 0.67 & 0.62 \\
\hline 3. & $\begin{array}{l}\text { The AC reviews and } \\
\text { monitors EA reports } \\
\text { concerning } \\
\text { statements. }\end{array}$ & 0.94 & 0.90 & 0.87 & 0.69 & 0.75 & 0.99 & 0.63 & 0.68 & 0.45 & 0.53 & 0.99 \\
\hline 4. & $\begin{array}{l}\text { The AC reviews } \\
\text { corrections made by } \\
\text { management to financial } \\
\text { statements. }\end{array}$ & 0.21 & 0.12 & $0.04^{*}$ & 0.18 & 0.54 & 0.77 & 0.42 & 0.24 & 0.40 & 0.11 & 0.43 \\
\hline
\end{tabular}

Taken together, the findings from the survey and the interviews suggest that while there appears to be a clear theoretical understanding of and support for this aspect of the AC's monitoring role, this is not always being translated into good practice. While most of the interviewees saw monitoring financial statements as one of the main roles of the AC, some argued that in practice, the committee does not have adequate time to review these financial statements. Instead, it limits itself to submitting reports and recommendations to the board for

2 The Kruskal-Wallis test was used to identify any statistically significant differences across the sample as a whole.

${ }^{3}$ The Mann-Whitney test was used to compare the mean values of pairs within the sample. 
discussion in board meetings. Nevertheless, ACs are in many cases playing an important role in the financial reporting process (Beasley et al., 2009; Campbell et al., 2013) and improving the reliability of financial reporting (Abernathy et al. 2013). These findings are consistent with agency theory's assumption that the AC as a mechanism of CG plays an important role in monitoring and enhancing financial statements, and that it reduces agency costs by enhancing the quality of information flows between principal and agent (Beasley et al., 2009).

\subsection{The Ac's Role In The Internal Audit Function}

The survey respondents were asked to indicate the extent to which they agreed that the given statements described tasks undertaken by the $\mathrm{AC}$ as part of its internal audit role. Table 3 shows that overall, the five groups expressed the strongest agreement with statement 2 (The AC reviews the internal audit reports". The second most strongly supported statement was number 6 ("The AC promotes the independence of the internal auditors"), followed by statement 1 ("The AC reviews the objectives, plan and functions of the internal audit"), statement 4 ("The AC receives reports on the results of internal auditors' work"), statement 8 ("The AC reviews the effectiveness of internal controls"), statement 7 ("The AC recommends the appointment or replacement of internal auditing directors"), statement 3 ("The AC ensures that the internal audit has the necessary resources") and finally, statement 5 ("The AC meets with the head of internal auditing without the presence of management"). The rank order notwithstanding, these mean values show that the sample as a whole agreed that ACs in Libya perform all of these tasks as part of their internal audit role. Breaking the responses down by group, the $\mathrm{AC}$ group was the most convinced of the $\mathrm{AC}^{\prime}$ s role in the internal audit function (group mean 3.89), while the EM group was the least convinced (3.61). Once again, the lower mean score from the EM group may mean that the executive managers in the sample were less than satisfied with how ACs in the LBS perform this role. However, this may be partly attributable to sensitivity on the part of executive managers - they may not like the fact that internal auditors are supervised by the AC rather than by the management, and that the internal audit department reports on the work of other departments directly to the committee (limiting managers' opportunities for manipulation). The Cronbach's Alpha result for this question was 0.85 .

Table 3: Descriptive Statistics on the Role of the AC in the Internal Audit Function

\begin{tabular}{|c|c|c|c|c|c|c|c|c|c|c|c|}
\hline \multirow{2}{*}{ No } & \multirow{2}{*}{ Statements } & \multicolumn{5}{|c|}{ Group Means } & \multirow{2}{*}{$\begin{array}{l}\text { Total } \\
\text { Mean } \\
\text { Score }\end{array}$} & \multirow{2}{*}{ Median } & \multirow{2}{*}{$\begin{array}{l}\text { Standard } \\
\text { Deviation }\end{array}$} & \multirow[b]{2}{*}{ Rank } & \multirow{2}{*}{$\begin{array}{l}\text { Cronbach's } \\
\text { Alpha }\end{array}$} \\
\hline & & $\mathrm{BD}$ & $\mathrm{AC}$ & EM & IA & EA & & & & & \\
\hline 1. & $\begin{array}{l}\text { The AC reviews the objectives, plan } \\
\text { and functions of the internal audit }\end{array}$ & 4.10 & 3.82 & 3.55 & 3.93 & 3.91 & 3.81 & 4.00 & 0.98 & 3 & \\
\hline 2. & $\begin{array}{l}\text { The AC reviews the internal audit } \\
\text { reports }\end{array}$ & 4.05 & 3.94 & 3.88 & 3.93 & 4.09 & 3.95 & 4.00 & 0.93 & 1 & \\
\hline 3. & $\begin{array}{l}\text { The AC ensures that the internal audit } \\
\text { has the necessary resources }\end{array}$ & 3.52 & 3.94 & 3.55 & 3.73 & 3.66 & 3.66 & 4.00 & 1.05 & 7 & \\
\hline 4. & $\begin{array}{l}\text { The AC receives reports on the results } \\
\text { of internal auditors' work }\end{array}$ & 3.91 & 3.53 & 3.68 & 3.90 & 3.71 & 3.77 & 4.00 & 1.05 & 4 & 0.85 \\
\hline 5. & $\begin{array}{l}\text { The AC meets with the head of internal } \\
\text { auditing without the presence of } \\
\text { management }\end{array}$ & 3.71 & 3.65 & 3.45 & 3.59 & 3.46 & 3.54 & 4.00 & 1.10 & 8 & \\
\hline 6. & $\begin{array}{l}\text { The AC promotes the independence of } \\
\text { the internal auditors }\end{array}$ & 3.86 & 4.41 & 3.68 & 4.00 & 3.69 & 3.86 & 4.00 & 0.98 & 2 & \\
\hline
\end{tabular}




\begin{tabular}{|c|c|c|c|c|c|c|c|c|c|c|}
\hline 7. & $\begin{array}{l}\text { The } \mathrm{AC} \text { recommends the appointment } \\
\text { or replacement of internal auditing } \\
\text { directors }\end{array}$ & 4.00 & 3.82 & 3.55 & 3.70 & 3.51 & 3.66 & 4.00 & 1.04 & 6 \\
\hline 8. & $\begin{array}{l}\text { The AC reviews the effectiveness of } \\
\text { internal controls }\end{array}$ & 3.67 & 4.00 & 3.54 & 3.88 & 3.71 & 3.73 & 4.00 & 0.88 & 5 \\
\hline & Overall Group Means & 3.85 & 3.89 & 3.61 & 3.84 & 3.72 & 3.75 & - & - & - \\
\hline
\end{tabular}

Figure 2 indicates that $78.5 \%$ of respondents agreed with statement 2 - the highest level of agreement for any statement - while statements 5 and 7 recorded the lowest levels of agreement, with 55.9\% and 55.5\% respectively. The results in Table 3 and Figure 2 are consistent with those of numerous other studies identifying the AC's role in the internal audit function and internal control systems (e.g. Cohen et al., 2004; Rich and Zhang, 2014; Bardhan et al., 2015; Alzebana and Sawan, 2015).

Figure 2: Overall Results for Respondents' Perceptions of the Role of the AC in the Internal Audit Function

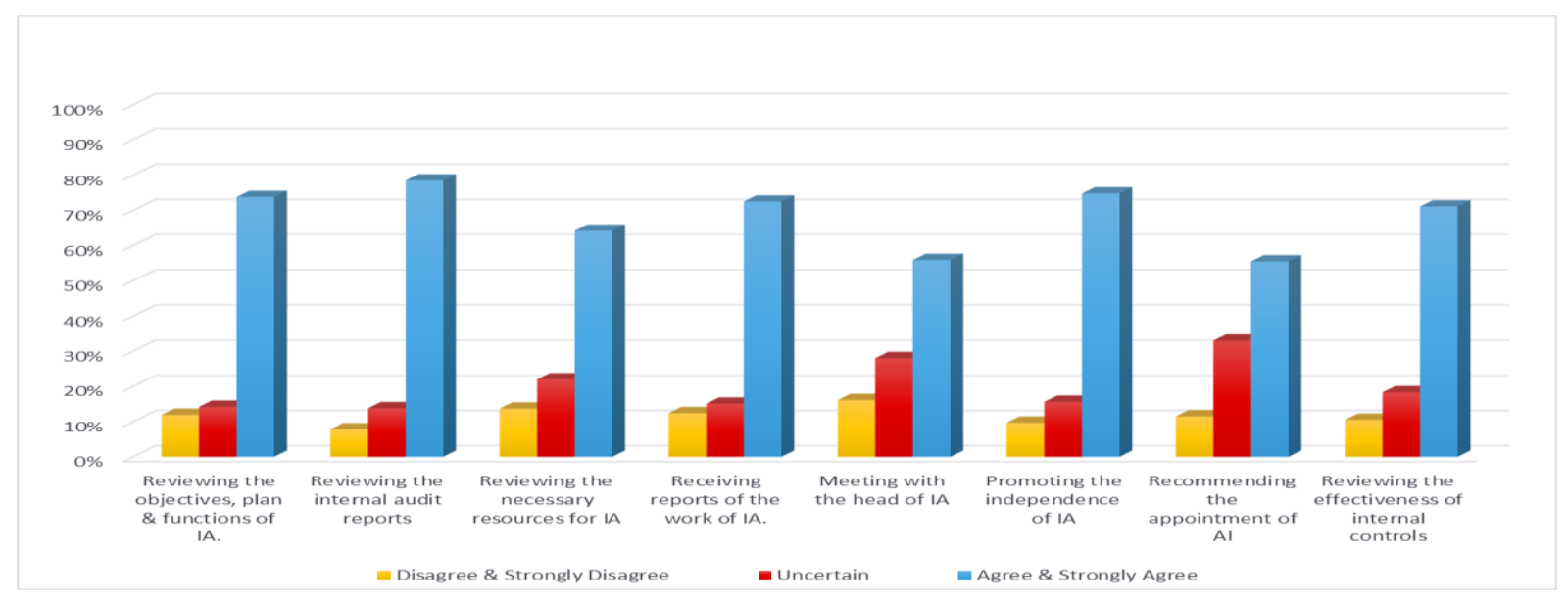

The Kruskal-Wallis test (see Table 4) highlighted that there were significant differences among the groups in regard to the $\mathrm{AC}^{\prime}$ s responsibility for reviewing the objectives, plan, functions and terms of reference of the internal audit (statement 1) and its promotion of internal auditors' independence (statement 6). The p-values for these two statements were 0.04 and 0.02 respectively. When the results for these two statements were explored further using the Mann-Whitney test, the results indicated that in most cases, it was the EM group that differed from the other groups. This was reflected in the overall group means for each group. As mentioned above, this difference may be partly attributable to sensitivity on the part of executive managers - they may not like the fact that internal auditors are supervised by the $\mathrm{AC}$ rather than by the management, and that the internal audit department reports on the work of other departments directly to the committee.

Table 4: Results of Between-Group Comparisons on the Ac's Role in the Internal Audit Function

\begin{tabular}{lccccccc}
\hline & & Kruskal- & \multicolumn{3}{c}{ Mann-Whitney Test - P-values } \\
\cline { 3 - 6 } & Statements & Wallis & BD-AC & BD-EM & BD-IA & BD-EA AC-EM AC-IA AC-EA EM-IA EM-EA IA-EA \\
\hline
\end{tabular}




\begin{tabular}{|c|c|c|c|c|c|c|c|c|c|c|c|c|}
\hline 1. & $\begin{array}{l}\text { The AC reviews the } \\
\text { objectives, plan and } \\
\text { functions of the internal } \\
\text { audit }\end{array}$ & $0.04^{*}$ & 0.22 & $0.02^{*}$ & 0.68 & 0.67 & 0.39 & 0.36 & 0.46 & $0.01^{*}$ & 0.05 & 0.95 \\
\hline 2. & $\begin{array}{l}\text { The AC reviews the } \\
\text { internal audit reports }\end{array}$ & 0.68 & 0.60 & 0.77 & 0.97 & 0.41 & 0.82 & 0.63 & 0.28 & 0.76 & 0.19 & 0.24 \\
\hline 3. & $\begin{array}{l}\text { The AC ensures that the } \\
\text { internal audit has the } \\
\text { necessary resources }\end{array}$ & 0.71 & 0.22 & 0.75 & 0.36 & 0.59 & 0.28 & 0.68 & 0.45 & 0.35 & 0.74 & 0.68 \\
\hline 4. & $\begin{array}{l}\text { The AC receives reports } \\
\text { on the results of internal } \\
\text { auditors' work }\end{array}$ & 0.39 & 0.40 & 0.39 & 0.66 & 0.50 & 0.74 & 0.22 & 0.73 & 0.08 & 0.96 & 0.21 \\
\hline 5. & $\begin{array}{l}\text { The AC meets with the } \\
\text { head of internal auditing } \\
\text { without the presence of } \\
\text { management }\end{array}$ & 0.75 & 0.77 & 0.31 & 0.51 & 0.35 & 0.52 & 0.84 & 0.49 & 0.44 & 0.93 & 0.41 \\
\hline 6. & $\begin{array}{l}\text { The AC promotes the } \\
\text { independence of the } \\
\text { internal auditors }\end{array}$ & $0.02^{*}$ & $0.04^{*}$ & 0.53 & 0.39 & 0.66 & $0.00^{*}$ & 0.06 & $0.02^{*}$ & $0.03^{*}$ & 0.92 & 0.14 \\
\hline 7. & $\begin{array}{l}\text { The AC recommends the } \\
\text { appointment or } \\
\text { replacement of internal } \\
\text { auditing directors }\end{array}$ & 0.38 & 0.58 & 0.06 & 0.24 & 0.10 & 0.32 & 0.68 & 0.37 & 0.41 & 0.98 & 0.48 \\
\hline 8. & $\begin{array}{l}\text { The AC reviews the } \\
\text { effectiveness of internal } \\
\text { controls }\end{array}$ & 0.14 & 0.19 & 0.53 & 0.33 & 0.71 & 0.05 & 0.53 & 0.35 & $0.03^{*}$ & 0.28 & 0.54 \\
\hline
\end{tabular}

${ }^{*} \mathrm{P}$-values $<0.05$

In summary, the survey respondents thought ACs currently perform all the activities as part of their internal auditing role. This finding, which was confirmed in the interviews, is consistent with those identified by previous authors including Cohen et al. (2004) and Alzebana and Sawan (2015). These authors all highlight the relationship and interaction between the AC and the internal audit department as a key factor in achieving effective CG. The majority of respondents pointed to the significant role the AC plays in overseeing the internal audit function, in resolving any problems and difficulties faced by the internal audit department and in recommending new appointments to the director's job. This is roughly consistent with the findings of Turley and Zaman (2007) and Ahmad et al. (2009). Finally, the majority of respondents highlighted the committee's role in overseeing internal control systems, which echoes Rich and Zhang (2014) and Bardhan et al. (2015). The findings thus seem to support agency theory's view that an effective AC can play a major monitoring role. However, they also illustrate that this effectiveness depends to some extent on the committee's relationship with the internal audit department, and as a number of interviewees pointed out, this relationship may not always be strong. Institutional theory may offer one explanation for this; ACs that have been established primarily for the purpose of creating legitimacy outside the organisation may be less inclined (or less able) to forge strong links with this department.

\subsection{The Ac's Role in The Work of The External Audit}

As may be observed in Table 5, respondents generally expressed weaker agreement with these statements than they did with the statements in the internal audit question suggesting that ACs play a less significant role in this process than they do in the internal audit function. This 
is reflected in the total mean scores; statement 2 ("The AC reviews the findings of the annual audit") scored highest with just 3.62. This was followed by statement 3 ("The AC reviews and investigates the audit fees"), statement 5 ("The AC recommends the appointment and replacement of the EA"), statement 1 ("The AC monitors the activities, resources, expertise and independence of the EA") and finally, statement 4 ("The AC meets the EA without the presence of management"). The bottom means are significantly lower than they were in the question relating to the AC's role within the internal audit function. When the means were aggregated across the five statements, this yielded overall group means of 3.69 (BD group), 3.55 (AC group), 3.36 (EA group), 3.32 (IA group) and 3.20 (EM group). As in the previous questions, the lowest mean score was produced by the executive managers, suggesting that they did not see ACs as playing a major role within the external audit function. Table 5 shows that the Cronbach's Alpha test yielded a result of 0.77 for this question.

Table 5: Descriptive Statistics on the Role of the AC in the External Audit Function

\begin{tabular}{|c|c|c|c|c|c|c|c|c|c|c|c|}
\hline \multirow{2}{*}{ No } & \multirow{2}{*}{ Statements } & \multicolumn{5}{|c|}{ Group Means } & \multirow{2}{*}{$\begin{array}{l}\text { Total } \\
\text { Mean } \\
\text { Score }\end{array}$} & \multirow{2}{*}{ Median } & \multirow{2}{*}{$\begin{array}{l}\text { Standard } \\
\text { Deviation }\end{array}$} & \multirow{2}{*}{ Rank } & \multirow{2}{*}{$\begin{array}{c}\text { Cronbach's } \\
\text { Alpha }\end{array}$} \\
\hline & & $\mathrm{BD}$ & $\mathrm{AC}$ & EM & IA & EA & & & & & \\
\hline 1. & $\begin{array}{l}\text { The AC monitors the activities, } \\
\text { resources, expertise and } \\
\text { independence of the EA }\end{array}$ & 3.62 & 3.18 & 3.03 & 3.13 & 3.37 & 3.18 & 3.00 & 1.09 & 4 & \\
\hline 2. & $\begin{array}{l}\text { The AC reviews the findings of } \\
\text { the annual audit }\end{array}$ & 4.05 & 3.65 & 3.57 & 3.58 & 3.54 & 3.62 & 4.00 & 0.98 & 1 & \\
\hline 3. & $\begin{array}{l}\text { The AC reviews and } \\
\text { investigates the audit fees }\end{array}$ & 3.52 & 3.59 & 3.28 & 3.65 & 3.37 & 3.46 & 4.00 & 0.99 & 2 & 0.77 \\
\hline 4. & $\begin{array}{l}\text { The AC meets the EA without } \\
\text { the presence of management }\end{array}$ & 3.43 & 3.77 & 2.92 & 3.00 & 3.17 & 3.10 & 3.00 & 1.08 & 5 & \\
\hline 5. & $\begin{array}{l}\text { The AC recommends the } \\
\text { appointment and replacement } \\
\text { of the EA }\end{array}$ & 3.81 & 3.59 & 3.20 & 3.25 & 3.34 & 3.33 & 3.00 & 1.10 & 3 & \\
\hline & Overall Group Means & 3.69 & 3.55 & 3.20 & 3.32 & 3.36 & 3.32 & - & - & - & \\
\hline
\end{tabular}

Figure 3 reveals that $58.3 \%$ of the survey respondents agreed with statement 2 , while just $37.6 \%$ agreed with statement 4 , but a huge $30.3 \%$ of participants were uncertain whether this responsibility is performed by ACs. These findings suggest that ACs in the LBS are not yet performing the full range of tasks necessary to carry out their role within the external audit function. This is in line with several previous studies that have found that external auditors generally see ACs as doing little to promote their work (Cohen et al., 2002; Turley and Zaman, 2004).

Figure 3: Overall Results for Respondents' Perceptions of the Role of the AC in the External Audit Function 


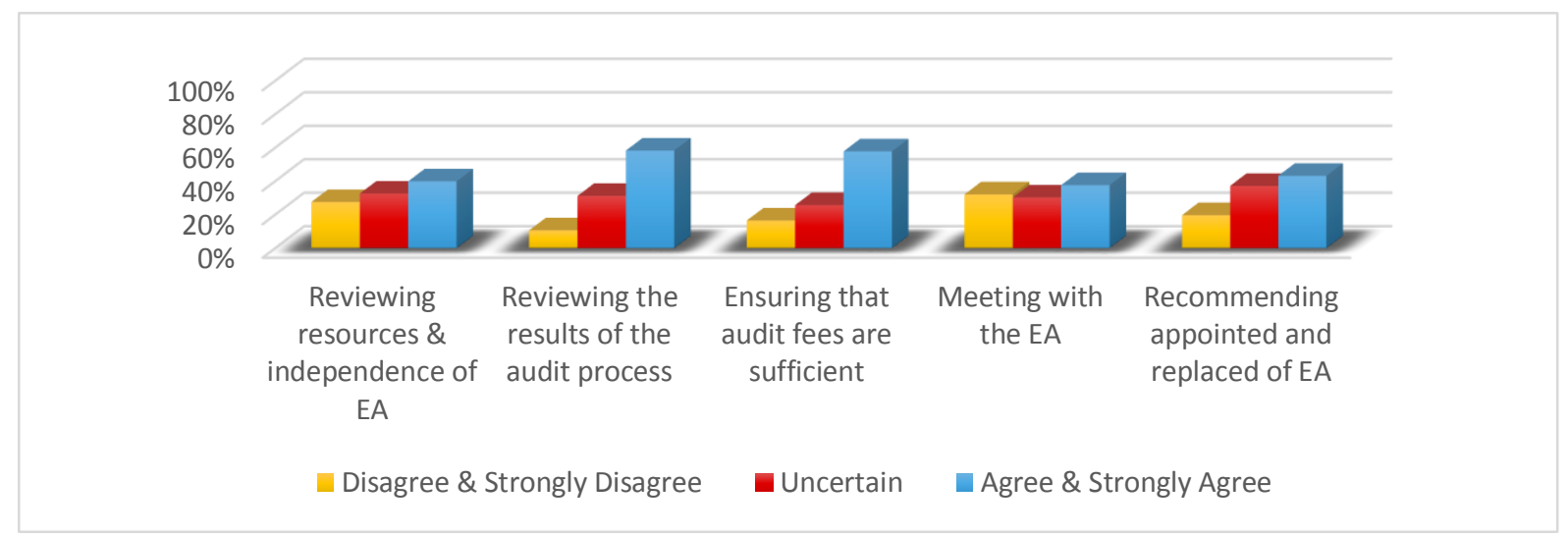

Table 6 shows no significant differences among the groups apart from on statement 4, which generated a p-value of 0.02 when the Kruskal-Wallis test was conducted. This statement concerned ACs meeting with external auditors without the presence of the management. However, when the Mann-Whitney test was conducted, significant differences emerged between pairs of groups on all but one of the statements. The higher level of support expressed for these statements by the BD and AC groups may be due to the fact that these groups are the most familiar with this aspect of the $\mathrm{AC}^{\prime}$ s role.

Table 6: Results of Between-Group Comparisons on the AC's Role in the External Audit Function

\begin{tabular}{|c|c|c|c|c|c|c|c|c|c|c|c|c|}
\hline \multirow{2}{*}{ NO } & \multirow{2}{*}{ Statements } & \multirow{2}{*}{$\begin{array}{c}\text { Kruskal- } \\
\text { Wallis }\end{array}$} & \multicolumn{10}{|c|}{ Mann-Whitney Test - P-values } \\
\hline & & & $\mathrm{BD}-\mathrm{AC}$ & BD-EM & BD-IA & BD-EA & AC-EM & AC-IA & AC-EA & EM-IA & EM-EA & IA-EA \\
\hline 1. & $\begin{array}{l}\text { The AC monitors the } \\
\text { activities, resources, } \\
\text { expertise } \\
\text { independence of the EA }\end{array}$ & 0.12 & 0.26 & $0.01^{*}$ & $0.04^{*}$ & 0.57 & 0.53 & 0.75 & 0.57 & 0.48 & 0.11 & 0.24 \\
\hline 2. & $\begin{array}{l}\text { The AC reviews the } \\
\text { findings of the annual } \\
\text { audit }\end{array}$ & 0.32 & 0.11 & $0.04^{*}$ & $0.03^{*}$ & 0.24 & 0.86 & 0.82 & 0.90 & 0.96 & 0.74 & 0.73 \\
\hline 3. & $\begin{array}{l}\text { The AC reviews and } \\
\text { investigates the audit fees }\end{array}$ & 0.37 & 0.74 & 0.34 & 0.77 & 0.70 & 0.23 & 0.86 & 0.55 & 0.05 & 0.64 & 0.35 \\
\hline 4. & $\begin{array}{l}\text { The AC meets the EA } \\
\text { without the presence of } \\
\text { management }\end{array}$ & $0.02^{*}$ & 0.24 & $0.03^{*}$ & 0.08 & 0.46 & $0.00^{*}$ & $0.01^{*}$ & 0.11 & 0.67 & 0.34 & 0.53 \\
\hline 5. & $\begin{array}{l}\text { The AC recommends the } \\
\text { appointment and } \\
\text { replacement of the EA }\end{array}$ & 0.09 & 0.56 & $0.01^{*}$ & $0.01^{*}$ & 0.19 & 0.15 & 0.22 & 0.54 & 0.84 & 0.45 & 0.60 \\
\hline
\end{tabular}

The modest levels of support expressed by the survey respondents regarding the $\mathrm{AC}^{\prime}$ s role in the external audit process are consistent with Cohen et al. (2002) and Bédard and Compernolle's (2014) findings that ACs tend to play a less significant role in this process than they do in the internal audit function. On the other hand, the interviews showed that many ACs do play a positive role in the external audit process, and that this contribution is valued. For example, several interviewees pointed to the committee's work liaising and resolving disagreements between external auditors, the board of directors and managers. Researchers are divided on the AC's effectiveness in this regard, with some arguing that such mediation is 
well within the power of a high-quality AC (Turley and Zaman, 2004; Keune and Johnstone, 2012) and others describing external auditor scepticism at the ability of these committees to address disagreements with management (Cohen et al., 2002). This scepticism on the part of external auditors may also explain the difficulties some ACs have when it comes to extracting information about deficiencies in the bank's control systems. Cohen et al. (2008) argue that external auditors should talk to the AC about any concerns and weaknesses within the organisation, but it seems that at present, this communication is often inadequate (Goff, 2013) - a problem compounded, according to Alrshah and Fadzil (2013), by the generally poor standard of external auditors in Libya. This significantly undermines the committee's ability to enhance the independence, effectiveness and objectivity of the external audit process.

\subsection{The Impact of The Shift to Islamic Law}

The transition from conventional into Islamic institutions is being made more difficult for many banks because of the speed at which this transition is taking place and pre-existing weaknesses in the banking environment. Given that the rapid shift to Islamic banking has the potential to significantly impact governance mechanisms, including AC, investigation of this topic was restricted to the interviews, where it was possible to elicit more detailed and nuanced responses from the participants.

When the interviewees were asked about the impact the transition to Islamic law is having on CG and AC practice in the LBS, the most optimistic response came from the board chairman of one of the state banks, who asserted that careful planning of the transition in his bank has meant that the application of Islamic law has had no adverse impact on CG or the AC. He stated that:

"Although the bank only began to implement Islamic law at the beginning of 2013, we have been steadily creating an Islamic banking business and have made a profit this year. I support the shift to Islamic banking, but we prefer the application to go step by step. There is an integrated plan for the bank to shift from the traditional system to the Islamic regime, so the application is not impacting on the work of the bank or its governance or AC".

However, the incorporation of Sharia into their commercial practices has different actions from those in conventional banks (Aribi and Gao, 2010), including their approach to CG (El-Halaby and Hussainey, 2016), particularly, because of the speed at which this incorporation is taking place in LBS. Thus, other interviewees were more concerned at the pace of the change, with the majority saying that the initiative is being pushed through too quickly in a banking environment that is already weak. The AC chairman from one mixed ownership bank was highly critical of the impact the rapid transition is having on the LBS and CG:

"In my view, the sudden application of Islamic law has significantly affected the work of banks and also CG and ACs. This sudden transition has caused a financial crisis for the LBS, without any solutions. Millions of Libyan Dinars have been lost because the traditional banking system has been stopped before the Islamic system is working as it should". 
The deputy head of Islamic banking from another mixed ownership bank expressed similar concern that the scale and pace of the shift may impact on CG and the AC:

"This is a new idea in Libya, and the bank is still in the early stages of shifting towards the Islamic system. We still need to change the systems used in the bank by retraining staff, changing the electronic system and the bank's financial statements, as well as forming a Sharia committee of three people. It might be preferable to make the shift gradually because a rapid transformation will affect the bank and hence governance and the $\mathrm{AC}^{\prime \prime}$.

The finding that the rapid enforcement of Islamic law in the LBS is likely to adversely affect practice in some banks is consistent with the UK Trade and Investment Report's (2014) conclusion that the transformation is being made more difficult by weaknesses in the Libyan banking environment. The interview findings also support Zaed et al. (2016), who note the lack of support from the CBL and the lack of trained staff, and Abdalla et al. (2015), who argue that Libya does not currently have the qualified staff or Islamic capital market it needs to transition successfully to Islamic banking. Finally, the study echoes Abdulsaleh (2017) and Elkrghli and Yahya (2018) in finding that many banks are still in the early stages of transformation. Although generally supportive of this transition, most interviewees wanted to see it happen gradually so that banks can learn from the experience of other countries and properly address the challenges associated with changing electronic systems and financial statements, retraining employees, establishing Sharia committees and implementing AAOIFI standards. Even so, some were optimistic that Islamic law can be applied without any adverse impact on CG or ACs. These interviewees echoed Stela and Bardai (2013) and Masoud (2014b) in believing that Islamic finance will play a prominent role in Libya's long-term economic growth and provide a better alternative to the conventional banking system.

\section{Conclusion}

This study seeks to contribute to the literature by exploring the role of ACs in the LBS, as perceived by the survey respondents and interviewees, and the extent to which the application of Islamic law is seen as having an impact on the role of ACs.

The AC was generally perceived to play an important role in monitoring financial statements and the internal audit function. These perceptions are generally consistent with agency theory's assumption that the AC, as a key CG mechanism, plays a vital role in monitoring and enhancing the quality of financial statements and in reducing agency costs by improving the quality of information flow between principal and agent. However, a number of concerns were expressed by the interviewees regarding the practical effectiveness of ACs in this monitoring role. It was observed, for example, that ACs in the LBS often spend too little time reviewing financial statements, instead limiting themselves to submitting reports and recommendations for discussion by the board, and that they rarely challenge weaknesses in the work of internal auditors. Furthermore, their effectiveness in monitoring the internal audit function can be undermined by a weak relationship with the internal audit department. The respondents were less convinced of the AC's importance in monitoring the external audit process - it appears 
that committees seldom follow-up or supervise the work of external auditors and that they have limited ability to promote their independence - though several interviewees acknowledged that many ACs play a positive role by mediating between external auditors and managers. Institutional theory may offer one explanation for this state of affairs; it may be that ACs in the LBS are primarily designed to create legitimacy outside the organisation rather than to effect radical change within it. By creating an AC, a bank signals its willingness to comply with the LCGC. This may indeed help the organisation become more effective, but an equally important driver may be that it is also likely to improve the bank's public reputation.

As far as the second research question is concerned, the study found that the LBS is still in the early stages of implementing Islamic law, and that the shift to an entirely Islamic banking system has not yet been accomplished. The findings indicate that it is not the application of Islamic law per se that is perceived as having an adverse impact on AC practice in the LBS, but the speed at which this transition is taking place. Most of the interviewees expressed concern that the transition is being made more difficult by weaknesses within the banking environment, including a lack of support from the CBL, a lack of trained staff and an inadequate Islamic capital market.

The findings suggest that greater attention needs to be paid to CG and ACs within the legal and regulatory environment in Libya; most importantly, the LCGC should be revised to place greater emphasis on the role of the AC. Banks themselves, meanwhile, need to conduct employee training and adopt AAOIFI standards in order to ensure that all their products and practices comply with Sharia rules and principles. The study contributes to the literature by offering a different perspective and new evidence from a country with its own unique business environment, culture, religion and regulatory framework. In broad terms, the findings add to our understanding of the $\mathrm{AC}^{\prime}$ 's role and how these committees operate outside developed countries, but more narrowly, they have specific implications for the board and AC members and regulators (particularly the CBL) in the LBS who are attempting to enhance the effectiveness of these committees.

Although the study has achieved the research aims and objectives and answered the research questions, it is nevertheless necessary to acknowledge its limitations. The first of these is the relatively small number of participants and interviewees. Given that these individuals were offering only their own perceptions and personal experiences, the gathered data may not reflect the views of the population as a whole. Furthermore, some may have even misrepresented their views or not told the truth because they did not want to present a negative impression of their firm. Future studies might include a longitudinal investigation to examine whether AC practice in Libya becomes more closely aligned with the LCGC recommendations over time. Moreover, given the severe shortage of research in developing countries, particularly Libya, further research is required that covers companies in other sectors within the Libyan economy or within other developing economies. 


\section{References}

Abdalla, M. A., Aziz, M. R., \& Johari, F., (2015). Analyzing The Impact of Banking Laws and Legislations on the Converting of Conventional Banks into Islamic in Libya. International Journal of Management and Applied Research, 2 (4), 156-171.

Abdou, M. A., (2015). Towards a New Solution of Minority Shareholder Protection in Libya: Letting the Minority Shareholders have a Voice. Ph.D. thesis, University of Glasgow.

Abdulsaleh, A.M., (2017). The introduction of Islamic finance in Libya: Capturing the opportunities for SMEs development. Journal of Emerging Economies E Islamic Research, 5 (1), 39-48.

Abernathy, J. L., Herrmann, D., Kang, T., \& Krishnan, G. V., (2013). Audit Committee Financial Expertise and Properties of Analyst Earnings Forecasts. Advances in Accounting, 29 (1), 111.

Ahmad, N., Othman, R., Othman, R., \& Jusoff, K., (2009). The Effectiveness of Internal Audit in Malaysian Public Sector. Journal of Modern Accounting and Auditing, 5 (9), 53-62.

Aldredge, M., Cooley, G. and Mallett, T., (2017). The Development of Theory in Accounting Research. Journal of Business and Management (IOSR-JBM), 19 (1), 27-29.

Al-Moataz, E., (2010). The Effectiveness of Audit Committees in the Kingdom of Saudi Arabia. Saarbrücken, Germany: Lap Lambert Academic Publishing.

Alrshah, A. M., (2015). An empirical analysis of audited financial statements reliability: Mediating role of auditor quality. International Journal of Finance and Accounting, 4 (3), 172-179.

Alrshah, A.M. and Fadzil, F., (2013). The impact of Corporate Governance reforms on External Auditor Quality and Reliability of Audited Financial Statements: Evidence from Libya. In: International Conference on Business Innovation, Entrepreneurship and Engineering (ICOBIEE2013), Penang, Malaysia, 6th to 8th December 2013. pp. 1-10.

Alzeban, A. and Sawan, N., (2015). The impact of audit committee characteristics on the implementation of internal audit recommendations. Journal of International Accounting, Auditing and Taxation, 24, 61-71.

Aribi, Z.A. and Gao, S., (2010). Corporate social responsibility disclosure: A comparison between Islamic and conventional financial institutions. Journal of Financial Reporting and Accounting, 8 (2), 72-91.

Bardhan, I., Lin, S. and Wu, S., (2015). The quality of internal control over financial reporting in family firms. Accounting Horizons, 29 (1), 41-60.

Barghathi, Y., Collison, D. and Crawford, L., (2017). Earnings management in Libyan commercial banks: perceptions of stakeholders. International Journal of Accounting, Auditing and Performance Evaluation, 13 (2), 123-149. 
Beasley, M. S., Carcello, J. V., Hermanson, D. R., \& Neal, T. L., (2009). The audit committee oversight process. Contemporary Accounting Research, 26 (1), 65-122.

Bédard, J. and Compernolle, T., (2014). The External Auditor and the Audit Committee. Routledge Companion to Auditing, Edited by David Hay, W. Robert Knechel and Marleen Willekens, 2014., Available at SSRN: https://ssrn.com/abstract=2423389.

Blue Ribbon Committee on Improving the Effectiveness of Corporate Audit Committees., (1999). Report and recommendations of the blue ribbon committee on improving the effectiveness of corporate audit committees. New York: New York Stock Exchange and National Association of Securities Dealers.:

Boubakri, N., Cosset, J. and Guedhami, O., (2005). Liberalization, corporate governance and the performance of privatized firms in developing countries. Journal of Corporate Finance, 11 (5), 767-790.

Braswell, M., Daniels, R. B., Landis, M., \& Chang, C. A., (2012). Characteristics of diligent audit committees. Journal of Business \& Economics Research (JBER), 10 (4), 191-206.

Campbell, J.L., et al., (2013). Are audit committee stock options, non-option equity and compensation mix associated with financial reporting quality? [online], pp. 1-53. Available at: https:/www.globalequity.org/geo/sites/default/files/SSRN-id1937170.pdf. [Accessed 18 March 2018].

Central Bank of Libya (CBL), (2010). Executive Position for Monetary and Banking Policy - During the Period 2002-2010. Tripoli - Libya.

Cohen, J. R., Gaynor, L. M., Holder-Webb, L. L., \& Montague, N., (2008). Management's discussion and analysis: Implications for audit practice and research. Current Issues in Auditing, 2 (2), A26-A35.

Cohen, J., Krishnamoorthy, G., \& Wright, A. M., (2002). Corporate governance and the audit process. Contemporary Accounting Research, 19 (4), 573-594.

(2004). The corporate governance mosaic and financial reporting quality. Journal of Accounting Literature, 87-152. Available at SSRN: https://ssrn.com/abstract=1086743.

Corbin, J. and Strauss, A., 2008. Basics of qualitative research: Techniques and procedures for developing grounded theory. 3rd ed. Thousand Oaks, California: Sage Publishing Inc.

Eldlimi, M. A., Aziz, M. R. A., \& Ibrahim, M. F., (2013). Implementing management information system in Libyan Islamic financial institutions. The 5th Islamic Economic System Conference (IECONS 2013), at Berjaya Times Square, Kuala Lumpur.

Elgharbawy, A., et al., (2016). Does compliance with corporate governance code hinder corporate entrepreneurship? Evidence from the UK. Corporate Governance, 16 (4), 765784. 
Elkrghli, S. and Yahya, A., (2018). Bankers' Views Towards Islamic Banking and Islamic Marketing: The Case of Libyan Main Wahda Bank in Benghazi City. Management Studies, 6 (1), 37-55.

Fichtner, J. R., (2010). The recent international growth of mandatory audit committee requirements. International Journal of Disclosure and Governance, 7 (3), 227-243.

FISS, P.C., (2008). Institutions and Corporate Governance. In: Greenwood, R., ET AL., 2008, ed., The SAGE Handbook of Organizational Institutionalism. London: Sage Publication Ltd, 2007, pp. 389-410.

Gitundu, E.W., et al., (2016). The Effects of Ownership and Corporate Governance Reforms on Efficiency of Privatized Companies in Kenya. International Journal of Economics and Financial Issues, 6 (1).

Goff, M., (2013). An Accounting Student's Take on the PCAOB's New Auditing Standard: No. 16. Journal of Creative and Scholarly Works [online], pp 30-35. Available at: http://www.highpoint.edu/urcw/files/2013/07/innovation-FINAL-VERSION-vol1.pdf\#page=30. [Accessed 05 March 2017].

Greenwood, R., Hinings, C. and Whetten, D., (2014). Rethinking institutions and organizations. Journal of Management Studies, 51 (7), 1206-1220.

Greenwood, R., Oliver, C., Suddaby, R., \& Sahlin-Andersson, K., 2008. The SAGE Handbook of Organizational Institutionalism. London: Sage Publication Ltd, 2007.

Hussainey, K. and Hassanein, A., (2017). Guest Editorial. Journal of Financial Reporting and Accounting, 15 (3), 266-268.

Hussey, J., \& Hussey, R., (1997). Business research: A practical guide for undergraduate and postgraduate students. Basingstoke, UK: Palgrave MacMillan

Iswaissi, H. and Falahati, K., 2017. Challenges to Corporate Governance Practices: Case Study of Libyan Commercial Banks. Corporate Governance and Sustainability Review, 1 (1), 33-42.

Kalbers, L. P., \& Fogarty, T. J., (1998). Organizational and economic explanations of audit committee oversight. Journal of Managerial Issues, 10 (2), (Summer 1998), 129-150.

Keune, M. B., \& Johnstone, K. M., (2012). Materiality judgments and the resolution of detected misstatements: The role of managers, auditors, and audit committees. The Accounting Review, 87 (5), 1641-1677.

Khlif, H. and Samaha, K., (2016). Audit committee activity and internal control quality in Egypt: does external auditor's size matter? Managerial Auditing Journal, 31 (3), 269-289.

Larbsh, M.M., (2010). An Evaluation of Corporate Governance Practice in Libya: Stakeholders' Perspectives. Ph.D. thesis., Nottingham Trent University. 
Liao, C. and Hsu, A.W., (2013). Common Membership and Effective Corporate Governance: Evidence from Audit and Compensation Committees. Corporate Governance: An International Review, 21 (1), 79-92.

Magrus, A. A. A., (2012). Corporate Governance Practices in Developing Countries: The Case of Libya. Ph.D. thesis., University of Gloucestershire.

Mangena, M. and Pike, R., (2005). The effect of audit committee shareholding, financial expertise and size on interim financial disclosures. Accounting and Business Research, 35 (4), 327-349.

Masoud, N., (2014a). What the Libyan Economy Can Learn from Emerging Countries. In: The 2010 University of Huddersfield Annual Learning and Teaching Conference, University of Huddersfield, Huddersfield, UK: Available at SSRN: https://ssrn.com/abstract=2429827

(2014b). Does Islamic banking contribute to Sharia law: Critical issues on Libyan banking and financial markets. [online], (April 17, 2017) Available at: SSRN https://papers.ssrn.com/sol3/papers.cfm?abstract_id=2426291_.

Okeahalam, C.C., (2004). Corporate governance and disclosure in Africa: Issues and challenges. Journal of Financial Regulation and Compliance, 12 (4), 359-370.

Oxner, T. and Oxner, K., (2006). Boom time for internal audit professionals: thanks to the profession's growing stature, internal auditors are enjoying higher salaries and greater career opportunities, The IIA's latest Job Market Survey reports. The Internal Auditor: Journal of the Institute of Internal Auditors, 63.2006 (3), 50-57.

Pietkiewicz, I. and Smith, J.A., (2014). A practical guide to using interpretative phenomenological analysis in qualitative research psychology. Psychological Journal, 20 (1), 7-14.

Ramlan, R., Omar, S. S., Chan, S. W., Yassin, A. M., \& Joy, C. K., (2015). Knowledge management in NGOs: A preliminary study in Malaysia. Advanced Science Letters, 21 (5), 1579-1583.

Rezaee, Z., (2009). Corporate Governance and Ethics. New York, USA: John Wiley \& Sons, Inc.

Rich, K. T., \& Zhang, J. X., (2014). Does audit committee monitoring matter in the government sector? evidence from municipal internal control quality. Journal of Governmental \& Nonprofit Accounting, 3 (1), 58-80.

Ritchie, J., et al., (2013). Qualitative research practice: A guide for social science students and researchers. 2nd ed. London: Sage Publishing Ltd.

Rustam, S., Rashid, K., \& Zaman, K., (2013). The relationship between audit committees, compensation incentives and corporate audit fees in Pakistan. Economic Modelling, 31, (March), 697-716. 
Saunders, M., Lewis, P., \& Thornhill, A., (2009). Research methods for business students (5th ed.). Harlow, UK: Pearson Education Limited.

Schroeder, R.G., Clark, M.W. and Cathey, J.M., (2014). Financial accounting theory and analysis: text and cases. 12th ed. Hoboken, NJ, USA: John Wiley \& Sons, Inc.

Smith, R., (2003). Audit committees combined code guidance: A report and proposed guidance by an FRC-appointed group. London: Financial Reporting Council (FRC).

Solomon, J., (2013). Corporate Governance and Accountability 4th ed. Chichester, UK: John Wiley \& Sons.

Stela, A. and Bardai, B., (2013). The Extent of Market Acceptance of the Development of an Effective Islamic Banking System in Libya. Journal of Economics, Business and Management, 1 (1), 54-56.

Stela, A.K.A. and Abdulsalam, A.A.A., (2016). The Citizens satisfaction level on the Islamic banking system of Libya. Journal of Economics and Finance (IOSR-JEF), 7 (6), 12-22.

Turley, S. and Zaman, M., (2004). The corporate governance effects of audit committees. Journal of Management and Governance, 8 (3), 305-332.

(2007). Audit committee effectiveness: informal processes and behavioural effects. Accounting, Auditing \& Accountability Journal, 20 (5), 765-788.

(2014). The corporate governance effects of audit committee. Accounting and regulation. Berlin, Germany: Springer, 2014, pp. 133-159.

UK Trade \& Investment, (2014). Libya: 2014/2015 Discovering Business: London UK: Allurentis Limited. Available at: http://www.libyaholdings.com/pdf/Libya-Discovering-Business2014.pdf [Accessed 15 March 2016].

Zaed, M., Garoum, O. and Aldaif, M., (2016). Origin of the Islamic Banking Business in Traditional Libyan Banks. International Journal of Scientific and Research Publications, 6 (4), 422-425.

Zagoub, A. A., 2016. Concept and practices of corporate governance in Libyan commercial banks: A stakeholders perspective. Journal of Economics and Business Studies, 3 (2), 1-14. 